\title{
Professionalism interrupted? Professionalism's challenges to local knowledge in New Zealand counselling
}

\section{Judi H Miller}

University of Canterbury, New Zealand

\begin{abstract}
In 2009, the New Zealand Association of Counsellors applied for statutory registration under the Health Practitioners Competence Assurance Act (2003). Contrary to the possible unification of members, this move exposed divisions within the New Zealand Association of Counsellors and threatened to undermine advances to incorporate culturally sensitive practices into the association's policies. This article suggests that attempts to professionalize counselling in New Zealand require the complementary use of two potentially conflicting forms of professionalism: organizational professionalism (represented in the need to raise counselling membership standards for registration), and occupational professionalism (represented in the form of resistance to a process that will exclude some members because their traditional ways of working and local knowledge may not be accepted by a registration board). At stake is a form of local knowledge, Māori theories of wellbeing and ways of working, that has been incorporated into the New Zealand Association of Counsellors' policies but which may not be accepted as essential to the protocols of statutory registration. As a case study, this highlights that in a postcolonial society, both organizational and occupational professionalism are required to negotiate occupational change and both are interrupted when local knowledge is seen as a centrally important value.
\end{abstract}

\section{Keywords}

Counselling, local knowledge, New Zealand, professionalism

\footnotetext{
Corresponding author:

Judi H Miller, School of Health Sciences, University of Canterbury, Dovedale Avenue, Christchurch 804I, New Zealand.

Email: judi.miller@canterbury.ac.nz
} 


\section{Introduction}

Evetts (2005) argues for a shift in analytical focus away from the concepts of profession and professionalization and towards the concept of professionalism and how it is being used. She specifically encourages interest in the way ideas of professionalism are now being used to advance occupational change and managerial control. Evetts (2010) posits that a focus on how professionalism is being used enables us to explore whether or not relationships of trust, discretion and competence are being challenged by new organizational forms of regulation such as accountability and target-setting.

In this article, I use a case study of New Zealand counselling ${ }^{1}$ to explore how relationships of trust, discretion and competence have been and continue to be challenged by organizational forms of regulation. Because counselling in New Zealand is an occupation without statutory regulation, its development over four decades has been interrupted by external pressures to professionalize. While other related occupations, psychology, psychotherapy and social work, have sought statutory registration, counselling has resisted it. At stake are not just relationships of trust, discretion and competence, but also autonomy and local knowledge. I use a thematic analysis of two decades of New Zealand Association of Counsellors documents, in-house newsletters and annual reports, and focus on two key events - professionalism imposed by a third-party funder and professionalism required by registration - to explore how challenges are negotiated during occupational change.

\section{Theoretical background}

The sociological study of professions has spanned three-quarters of a century with an early focus on establishing the ideal-typical characteristics of professions and professionalism and determining those occupations that met these criteria (Goode, 1957; Greenwood, 1957). Later, critical analysis focused on the process undertaken by occupations to gain professional status: professionalization (Abbott, 1988; Larkin, 1983; Larson, 1977; Wilensky, 1964). While some suggest a decline in sociological analyses of professions in the 1990s due to a perceived inability of frameworks to address societal changes that led to a transformation of professional work, there is other evidence of a current resurgence in studies of professions (Gorman and Sandefur, 2011). In their review of current research on work and occupations Gorman and Sandefur (2011) note that researchers' focus has expanded to include a broader range of occupations than traditional professions. They also note that four themes important to the sociology of professions remain. These are: expert knowledge; autonomy; a normative service orientation supported by a community; and status, income and rewards.

One example of recent work is that of Evetts $(2005,2011)$, who concentrated her research on occupational groups including head teachers, engineers, bankers and social workers. She has also argued for a shift in analytical focus away from the concepts of profession and professionalization towards the ideology of professionalism and how it is being used. In keeping with the conclusions of Gorman and Sandefur (2011), Evetts proposes that professionalism incorporates the view that the value of a profession is based on competence (expert knowledge), a strong occupational identity (autonomy), trust (a 
normative service orientation supported by a community) and cooperation. Using McClelland's (1990) categorization of professionalization 'from within' (successful manipulation of the market by the group) and 'from above' (domination of forces external to the group), Evetts posits that the appeal of professionalism should be recognized as a powerful instrument of occupational change and social control across diverse occupational groups. Her thesis is that there are two main ways in which professionalism is applied and used to benefit two different groups. The first she terms occupational professionalism which involves professional values of a shared identity based on autonomy and discretionary judgements by practitioners which depend on common and lengthy systems of education and are guided by codes of professional ethics monitored by professional associations. Occupational professionalism operates when the appeal to professionalism is made and used by the occupational group, 'from within' to benefit that group.

The second form of professionalism Evetts terms organizational professionalism, which incorporates hierarchical structures of responsibility, increased standardization of work procedures and externalized forms of regulation and accountability used by managers and employers to control the work of employees. Organizational professionalism operates when the appeal to professionalism is being imposed 'from above' by employers and managers to promote change and impose regulation of practice. The effect of organizational professionalism is the imposition of organizational objectives that 'regulate and replace occupational control in practitioner-client relations, thereby limiting the exercise of autonomy and discretion and preventing the service ethic that is so important in professional work' (Evetts, 2011: 408). Nevertheless, Evetts proposes that despite this regulation of work 'from above' the ideology of professionalism is often welcomed by many members of the occupational group because it is perceived as a way of improving the occupation's status. Evetts (2011) also suggests that occupational and organizational professionalism may not be mutually exclusive and that there may be some challenges and opportunities involved in combining the two. She therefore encourages researchers to focus on the ways in which the ideology of professionalism is being used by occupational groups and to explore whether or not relationships of trust, discretion, competence and service are being challenged by new organizational forms of regulation.

In this article, I focus on the ways in which the ideology of professionalism is being played out for New Zealand counsellors and the ways in which relationships of trust, discretion, service and competence have been and are being challenged by the interaction of both organizational and occupational professionalism. Within this context, I will briefly demonstrate how the ideology of professionalism was initially used 'from within' to advance the counsellors' sense of professional identity but how organizational forces external to the group (a specific third-party funder of counselling) imposed regulatory standards. I then demonstrate that new strategies have developed as counselling adapted to the challenge, from within and from above, to incorporate Māori ${ }^{2}$ principles and practices in its professional identity. Finally, I propose that occupational professionalism was challenged again, from within, as the professional body attempted to seek statutory registration, using organizational professionalism, while retaining one form of local knowledge, the kaupapa Māori, or Māori-centred, approach to counselling. These events support Evetts' notion that the ideology of professionalism is a driving force for professional groups as they adapt to challenges from within and from above. 
For this article, I use the term local knowledge to refer to knowledge that is the polar opposite of generalized expertise (Geertz, 1983). These polar forms of knowledge find corollaries with the concepts of occupational and organizational professionalism. The relevance of this focus for a narrative on the development of New Zealand counselling is highlighted by Totton (1999), who has used the term local knowledge to examine some of the effects of the rush to professionalization in the British field of counselling and psychotherapy. Although he has not used the same sociological language as Evetts, he has suggested that the ideology of professionalism has created a situation where powerful groups within counselling and psychotherapy have encouraged the occupation to take on the ideal-typical characteristics of a profession in order to advance professional security. Thus, in the United Kingdom, psychotherapists and counsellors have responded to the political need for a body of expert knowledge by generating one - 'radically lengthening and widening trainings, "technicalising" every aspect of the work, inserting new levels and meta-levels of expertise and qualification' (Totton, 1999: 317). The problem, articulated by Totton, and later by Davies (2009), is that the push towards standardization of clinical competence, an aspect of organizational professionalism, becomes subject to bureaucratic control and resists creative idiosyncrasy and initiative. Further, such standards are in direct contrast to the now considerable body of research which shows that successful therapeutic outcomes are not dependent on technique (Orlinsky and Howard, 1986; Seligman, 1995), rather they are dependent on the therapeutic alliance between the client and the practitioner (Duncan et al., 2009; Wampold, 2001). This alliance, which depends on the relationship between the client and the counsellor, is more reliant on the intuition, sensitivity and experience of the counsellor than on technique. Its importance for successful client outcomes is promoted in recent therapeutic approaches that are based on social constructionism such as Narrative and Solution-focused therapies (Duncan et al., 2009). The organizational problem is that the therapeutic alliance is less easily measured and evaluated than the diagnostic and treatment procedures of other therapies (Franklin et al., 2012). Totton's thesis is that recent resistance to the drive towards professionalism in Britain comes from concern that organizational professionalism will undermine the value of counsellors' effective use of the therapeutic alliance. 'Many practitioners ... have revolted against professionalisation, because it so directly flouts all their "local knowledge" - what they have learnt in practice about the interactions which are central to their craft; and because it means organising collectively in a way which actively contradicts their skilled understanding of human nature and human groups' (Totton, 1999: 322; emphasis in original). In New Zealand, an added dimension to this general 'local knowledge' is a specific form of local knowledge - the kaupapa Māori, or Māori-centred approach to counselling and this is similarly threatened by a rush towards organizational professionalism.

The New Zealand Association of Counsellors is currently seeking statutory registration using the ideology of organizational professionalism. The Executive of the Counsellors' Association is finding that its membership is divided on this issue. Some members support the accountability inherent in organizational professionalism as they see it as beneficial to their own professional security. Others, however, hold the values of occupational professionalism and resist the introduction of registration because it will be expensive, will exclude some members and does not guarantee better service for clients. 
I suggest that at stake are their assumed professional foundations of collegiality and autonomy to set occupational membership requirements, including knowledge, skills, standards of education and training. Of special interest is the impact this has had on the recent attempts by the Association to integrate Māori philosophies and practices, local knowledge, into all of its policies.

\section{New Zealand counselling buffeted between occupational and organizational professionalism}

The development of counselling in New Zealand was similar to that in the UK and US, where its origins were mainly in vocational guidance. An important difference, however, has been the way that the NZ government has supported counselling's development by providing funding to educational institutions to address social issues. In the $1930 \mathrm{~s}$, as part of the first Labour government's promotion of full employment, accessible health provision and free education, a state-funded vocational guidance service was established to assist the career development of school students. In the 1960 s the government complemented this service with the establishment of a school guidance service to address the perceived increase in socially, educationally and behaviourally troubled adolescents (Hermansson and Webb, 1993). In 1973, the first university-based course began to train both vocational guidance and school guidance counsellors.

Therapeutic counselling for a broader age range of people was conducted in fully subsidized government or quasi-government environments such as hospitals and community health agencies. The telephone service Lifeline, established by churches in the early 1960s, later became community based. The government also employed or financially supported social workers and a diverse group of lay helpers, such as marriage guidance counsellors, Samaritan telephone counsellors and church-based welfare workers.

The early 1980s heralded the advent of rapid neoliberal political change in New Zealand and the adoption of processes of reregulation in support of market, rather than governmental, allocation of resources, but with the government setting standards of accountability and quality of practice (Miller, 2004). As a result of these changes, counsellors, like other helping occupations, rallied to find new ways to define themselves and their work, occupational professionalism. The New Zealand Counselling and Guidance Association, which began in the 1970s as a small interest group $(n=60)$ of mainly school guidance counsellors, used the ideology of professionalism to guide this process (Miller, 1996). Association documents (in-house newsletters and annual reports) describe the draft criteria for membership, aims and constitution and a brief Code of Ethics. The initial Association focus was to claim occupational identity for school and vocational guidance counsellors and to set training standards (expert knowledge) for these groups. In the 1980s, in response to the political changes, the Association changed its name to the New Zealand Association of Counsellors and members began to explore the possibility of regulating the term counsellor. Although regulation was supported from within, it was not ratified by government, because at that time government was restricting its regulation of occupations, and so the term counsellor continued to be unprotected. 
In 1988, forces external to the occupational group were able to use the value of professionalism to impose some standards of accountability on counsellors. This came about as a result of a policy change within an agency that provides state-supported assistance to people who have experienced physical or psychological injury as a result of an accident. In 1988, counselling first appeared as a recommended service eligible for statesupported assistance to people who had experienced physical trauma. The agency providing this funding was the Accident Rehabilitation and Compensation Insurance Corporation (ACC), which is unique to New Zealand as it provides compensation for people with injuries resulting from accidents on a no-fault basis (Miller, 2004). A further unique aspect of this agency is that as a result of lobbying from women's groups, the agency defines sexual abuse as an accident for which compensation is granted. This means that people who have experienced sexual abuse are eligible to receive ACC funding for counselling. When opening up this new avenue of work for counsellors, ACC insisted that counsellors' eligibility to receive payment be conditional on membership of a recognized professional association.

At that time, the New Zealand Association of Counsellors had the least restrictive entry requirements among occupations providing therapeutic help and counsellors with a range of educational credentials and experience levels sought and gained membership (see Miller, 1996, 2004). Official documents demonstrate the influence this policy had in this early period on rising membership numbers, from 350 in 1990, to 1800 in 1994, and on the rising proportions of private practitioner members, from $20 \%$ in 1990 , to $50 \%$ in 1994 (Hermansson and Webb, 1993; Miller, 1996).

The New Zealand Association of Counsellors, however, had not secured statutory registration of counsellors, so ACC also had considerable influence on its policies. In response to this funder's requirements (organizational professionalism from above), changes were instituted in the Association's Code of Ethics, membership criteria, qualification standards and subscription fees. This situation undermined members' long-standing belief in autonomy and threatened to marginalize some models of counselling practice that are culturally informed rather than underpinned by academic credentials. In this instance, I am referring to counselling influenced by Māori principles and practices.

\section{Māori}

The Māori migrated from the islands of Polynesia by sea and settled in New Zealand around the 13th century AD. European explorers encountered Māori in 1642, and 1749, and by 1800 visits to New Zealand by European ships were frequent. By the 1830 s, the British Crown came under pressure to control the perceived lawlessness of European settlers and in 1840 a hastily drafted document called the Treaty of Waitangi was signed initially by the British Governor and 40 Māori chiefs and later by 500 Māori (Orange, 2004).

While the Treaty was an attempt by the British government to establish a system of property rights for land, the English and Māori language versions of the Treaty differ significantly and there is continual debate about exactly what was agreed. Subsequently Māori lost an increasing amount of their land, they went into a cultural and numerical 
decline and the Treaty was regarded as irrelevant to legal issues by successive governments (Durie, 1994).

By the late 20th century, persistence by Māori and changing government policies created the opportunity for changes in the legal position of the Treaty with the most significant event being its recognition in 1975 in the Treaty of Waitangi Act. Today the Treaty is regarded as the founding document of New Zealand comprising 'principles' of partnership, participation and protection which guide much of the Crown's public policy in relation to Māori (Boulton et al., 2009).

\section{Kaupapa Māori counselling - a form of local knowledge}

With the introduction of the Treaty of Waitangi Act some commentators have insisted that the Treaty text (both Māori and English) makes clear reference to Māori health and places obligations on the Crown to ensure that Māori health interests are actively protected (Kingi, 2007). Since the 1990s therefore, health care services in New Zealand have attempted to use contemporary Māori models of health and wellbeing to guide district health boards and health training institutions. Fundamental is an appreciation that western ways of working, that focus mainly on physical and psychological characteristics, may not be appropriate for Māori.

Māori models of health and counselling ${ }^{3}$ present a framework of good health where balance in four dimensions of wellbeing is essential. The four dimensions are te taha wairua (spiritual health), te taha hinengaro (emotional and psychological health), te taha tinana (physical health) and te taha whänau (a healthy family and social environment) (Durie, 2010). While there have been attempts to incorporate these models into psychology and psychotherapy, I suggest that incorporation has been limited by registration standards where western models are given precedence. In a document commissioned by the New Zealand Psychologists Board, a tohunga (Māori specialist) emphasized the difference between Māori and Pakeha approaches to counselling and psychology by commenting: 'we start with wairua first, then the hinengaro, then tinana, the healing of whakapapa (cultural identity) and then deal with trauma; whereas these others, they start with the trauma first and may or may not deal with the wairau, hinengaro, tinana, and whakapapa. There should be recognition of healing the wairua first, then the mind' (Milne, 2005: 19). Counsellors, however, have resisted registration in part, I suggest, because it may undermine the advances the New Zealand Association of Counsellors has made to incorporate Māori ways of working into its policies

\section{Organizational professionalism and the threat to local knowledge}

While the Treaty, its principles, and especially the notion of partnership, have remained part of a vigorous public debate (Crocket, 2009: 65), the New Zealand Association of Counsellors, like other professional groups, has written the Treaty of Waitangi into its constitutional documents. While these organizations do not have the same Treaty partnership responsibilities as the Crown, represented by the New Zealand government, they 
are expected to act in what the Royal Commission on Social Policy called the 'spirit of partnership' (1988: 53, quoted in Crocket, 2009). These organizations are thus expected to honour the national partnership.

A qualitative analysis of documents appearing in two decades of New Zealand Association of Counsellors newsletters, and annual reports provides evidence of several instances in which the Association has 'acted in the spirit of partnership' (Crocket, 2009; Miller, 2011). The first was a name change for the Association, from the New Zealand Counselling and Guidance Association to the New Zealand Association of Counsellors (NZAC), with the accompanying Māori title, Te Ropu Kaiwhiriwhiri o Aotearoa. This occurred in 1990 and was closely followed by the election of Tuti Aranui as a Life Member of the NZAC, in recognition for her advocacy for the small number of Māori counsellors within the Association and her work to support tauiwi (non-Māori) in appreciating Māori values. At the 1998 annual meeting a motion was passed 'That National Executive initiate development of parallel recognition of Māori Knowledge and expertise in the forthcoming year' (NZAC Newsletter, 1999: 19(1): 49). As a result, Te Whariki Tautoko (a network that sat alongside, but outside NZAC) was established to implement education and training appropriate to kaupapa Māori counselling (NZAC Newsletter, 2000: 21(1)).

The Association continued to promote the principle of partnership by adopting policies whereby at least one Māori member sat on membership interview panels and all members were to engage in cultural supervision. In 2006, the Association newsletter adopted a Māori subtitle (Nga Korero Awhina - 'the Speaking Helps') and in 2007 the Executive implemented a model of Māori representation on the National Executive, by appointing Te Ahi Kaa (the lightbearer) to represent Māori members and their interests.

This developing focus on kaupapa Māori counselling by the Association was interrupted by the passing of the Health Practitioners Competence Assurance Act 2003 (HPCAA) in 2004. The Act replaced occupational statutes governing medical practitioners, chiropractors, dentists, dieticians, medical laboratory technicians, nurses and midwives, occupational therapists, optometrists and opticians, pharmacists, physiotherapists and psychologists. Before the implementation of the HPCAA, each health profession was regulated under a profession-specific statute and in general the legislation did not require health practitioners to continue their professional education in new skills and technologies or to demonstrate that they had maintained their competence to practise. The new Act encapsulated organizational professionalism as it provided a framework for the regulation of health practitioners with the purpose of protecting the public where there is a risk of harm from the practice of the profession. It included mechanisms such as scopes of practice and standards to ensure that practitioners are competent and fit to practise their professions for the duration of their professional lives. It also provided a regulatory authority with the power to suspend a practitioner's Annual Practising Certificate or alter their scope of practice.

While psychologists, counselling psychologists and psychotherapists advocated for their scopes of practice to be included under the jurisdiction of the Act, counsellors did not. This meant that places in which counsellors could work were restricted and, in particular, they were not able to work in health institutions. Some counsellors began 
canvassing their Association to develop a case for a counselling scope of practice. The problem, however, was that to be regulated by the Act, counsellors needed to demonstrate specific expertise and given the diverse membership of the New Zealand Association of Counsellors, demonstration of expertise that was sufficiently different from that of psychotherapists was difficult. In addition, the move to registration was of particular concern to some members of the Association as it threatened to undermine the advances made to incorporate Māori values, philosophies and customs into the Association's policies.

While Māori ways of working have been written in general terms into scopes of practice in the HPCAA they focus mainly on ways non-Māori can demonstrate cultural competence. Cultural competence for psychologists and psychotherapists includes an informal appreciation of the cultural bias of psychological theories, models and practices and a commitment to modify practice accordingly. In Section 11 of the HPCAA it indicates that 'Psychotherapists shall be competent to use various methods of psychotherapy to assist clients in their personal growth, relationship development, psychological life issues and mental health problems, whilst taking into consideration the bicultural context of Aotearoa New Zealand.' These scopes and standards of competence, therefore, do not address the need to accept the expertise of Māori, and non-Māori, practitioners that is based on experience in kaupapa Māori counselling. This lack of acceptance is one of the reasons counsellors in the New Zealand Association of Counsellors lack unity about the value of statutory registration.

The current situation with respect to the Association's attempts to promote registration is as follows. In 2006 a regular feature on registration appeared in the Association newsletters and efforts were made by a working group to allay fears that long-serving counsellors who did not have recent qualifications and counsellors who worked in kaupapa Mäori ways would be excluded by registration (NZAC Newsletter, 2006: 26(4)). At the 2007 AGM university counsellor-educators put forward a remit to cancel the registration process and, as a result the Executive slowed the process. Nevertheless, organizational professionalism prevailed and in 2008, the Executive surveyed the membership. Fifty-two per cent of eligible members voted, with $70 \%$ in favour of registration and $29 \%$ opposed. In 2009, the Executive lodged an application for registration under the HPCAA 2003. The outcome of this application, and the impact on local knowledge, is still to be determined as the government has put a halt on all applications until a review of the Act has been completed.

\section{Discussion and conclusion}

The focus of this article has been, essentially, the professional project (Larson, 1977) of counselling in New Zealand. The possibility of counselling becoming registered under the HPCAA has resulted in divisions among the membership and confusion about the best direction to take to protect local knowledge.

The New Zealand Association of Counsellors was established with an undeveloped occupational identity and used the ideology of professionalism to guide early development. Despite the imposition of extra standards (organizational professionalism) on the Association by a third-party funder, the ACC, the ideology of occupational 
professionalism prevailed as members valued the competence implied by these standards and embraced them as if they were their own (Miller, 2004).

Alongside these developments, the Association attempted to include another value of professionalism, cooperation, by acting within the spirit of the Treaty of Waitangi. For over two decades, the Association found ways to demonstrate that it was taking seriously its Treaty responsibilities to value local, Māori, knowledge. While these developments put considerable pressure on the few Māori members who promoted them and were not always well received by all non-Māori members, they were accepted into policies by the membership and they did change the occupational identity of the Association. Throughout these developments the ideology of occupational professionalism (from within) prevailed.

A major change came about with the introduction of legislation that registered allied professional groups and threatened the livelihood of many private practitioners within the New Zealand Association of Counsellors membership. In response, the Association's Executive sought member approval to apply for counsellor registration under the HPCAA. The Act encompasses all the attributes of what Evetts (2011) terms organizational professionalism (social control in the form of accountability and regulation of standards). It also challenges the autonomy of the Association to determine levels of competence and discretion about membership. In the case of the New Zealand Association of Counsellors, this challenge has resulted in a shattering of occupational identity and reduction of cooperation as members pursue individual needs. For some, their priority is registration to open up more places of work for them; for others, their priority is to resist the process of registration as it will impose standards that rely on measurements that are not easily applied to a number of current counselling approaches. At the core of this resistance is one aspect of local knowledge, kaupapa Māori counselling, which is likely to be marginalized under statutory registration. Advocates of resistance point to the fact that, despite the occupations of psychology and psychotherapy having scopes of practice within the HPCAA, they have yet to develop Māori scopes of practice.

The situation that has resulted from this development has been the use by the Association Executive of both organizational and occupational professionalism. When communicating with members, through Association newsletters and annual reports, the Executive has promoted the need to gain exclusive status, to protect clients from nonregistered practitioners: organizational professionalism. It has also promoted the need for the Association to demonstrate to the state that the occupation has a strong occupational identity and that all members are trustworthy and competent to practise counselling in an ethical manner: occupational professionalism. These appeals to professionalism, however, are interrupted by the need for the Association to continue acting in the spirit of the Treaty and uphold the value of local knowledge which does not sit easily within the registration agenda.

This situation is consistent theoretically with the ways Evetts (2005) encouraged a focus on the use of professionalism to explore whether or not relationships of trust, discretion and competence are being challenged by new organizational forms of regulation. Her work has proven to be a useful framework for exploring the development of the New Zealand Association of Counsellors. This has enabled me to highlight how major events in its development have required the use of both organizational and occupational 
professionalism and have interrupted advocacy for professionalism from within and above the Association. Furthermore, it has demonstrated the importance of collective action within an occupational group when organizational professionalism threatens to undermine the value of local knowledge within that group. This suggests possibilities for using this analytical framework for exploring the development of other occupational groups, particularly those not usually classified as traditional professions.

\section{Funding}

This research received no specific grant from any funding agency in the public, commercial, or not-for-profit sectors.

\section{Notes}

1. Counselling involves the formation of professional relationships based on ethical values and principles. Counsellors seek to assist clients to increase their understanding of themselves and their relationships with others, to develop more resourceful ways of living, and to bring about changes in their lives. See New Zealand Association of Counsellors Code of Ethics, at: www. nzac.org.nz/code_of_ethics.cfm.

2. Māori are the first peoples of New Zealand.

3. As a non- Māori, I do not expect to provide all the nuances of kaupapa Māori counselling, but will provide sufficient information to support my view that this is a form of local knowledge.

\section{References}

Abbott A (1988) The System of Professions: An Essay on the Division of Expert Labour. Chicago: University of Chicago Press.

Boulton AF, Gifford HH and Potaka-Osborne M (2009) Realising Whanau Ora through community action: The role of Māori community health workers. Education for Health 22(2): 1-11.

Crocket A (2009) Interpreting 'partnership' as a core value: Some implications of the Treaty of Waitangi for the NZAC Code of Ethics. New Zealand Journal of Counselling 29(2): 61-72.

Davies J (2009) Psychotherapy and the third wave of professionalisation. European Journal of Psychotherapy and Counselling 11(2): 191-202.

Duncan BL, Miller SD, Wampold BE and Hubble MA (eds) (2009) The Heart and Soul of Change: Delivering What Works in Therapy. Washington, DC: American Psychological Society.

Durie M (1994) Whaiora Māori Health Development. Auckland, New Zealand: Oxford University Press.

Durie M (2010) Māori concepts of wellbeing. Seminar Notes, Christchurch, New Zealand: Compass, pp. 18-19.

Evetts J (2005) The management of professionalism: A contemporary paradox. Speech given at King's College, London, 19 October 2005.

Evetts J (2010) Organizational professionalism: Changes, challenges and opportunities. In: XIV IRSPM Conference 'The Crisis: Challenges for Public Management', University of Berne, 7-9 April 2010.

Evetts J (2011) A new professionalism? Challenges and opportunities. Current Sociology 59(2): 406-422.

Franklin C, Trepper T, Gingerich W and McCollum E (eds) (2012) Solution-focused Brief Therapy: A Handbook of Evidence-based Practice. New York: Oxford University Press.

Geertz C (1983) Local Knowledge: Further Essays in Interpretive Anthropology. New York: Basic Books. 
Goode WJ (1957) Community within a community: The professions. American Sociological Review 22: 194-200.

Gorman EH and Sandefur RL (2011) 'Golden age,' quiescence, and revival: How the sociology of professions became the study of knowledge-based work. Work and Occupation 38(3): 275-302.

Greenwood E (1957) Attributes of a profession. Health and Social Work 2(3): 45-55.

Hermansson G and Webb S (1993) Guidance and counselling in New Zealand: Weathering a decade of transformation. International Journal for the Advancement of Counselling 16(3): 213-229.

Kingi TR (2007) The Treaty of Waitangi: A framework for Māori health development. New Zealand Journal of Occupational Therapy 54(1): 4-10.

Larkin G (1983) Occupational Monopoly and Modern Medicine. London: Tavistock.

Larson MS (1977) The Rise of Professionalism. Berkeley: University of California Press.

McClelland CE (1990) Escape from freedom? Reflections on German professionalization 1870-1933. In: Torstendahl R and Burrage M (eds) The Formation of Professions: Knowledge, State and Strategy. London: Sage, pp. 97-113.

Miller JH (1996) From unity to diversity: An account of the growth, development and change in the New Zealand Association of Counsellors as identified through the Association newsletters. New Zealand Journal of Counselling 18(2): 36-49.

Miller JH (2004) Third-party funding and counselling in New Zealand: Implications for counselling services and professional autonomy. International Journal for the Advancement of Counselling 26(3): 285-299.

Miller JH (2011) More than a decade of considerable change: An interpretation of the New Zealand Association of Counsellors Newsletters 1997-2009. New Zealand Journal of Counselling 31(1): 1-15.

Milne M (2005) Māori perspectives on kaupapa Māori and psychology: A discussion document. New Zealand Psychologists Board.

Orange C (2004) An Illustrated History of the Treaty of Waitangi. Wellington: Bridget Williams Books.

Orlinsky DE and Howard KI (1986) Process and outcome in psychotherapy. In: Garfield SL and Bergin AE (eds) Handbook of Psychotherapy and Behavior Change, 3rd edn. New York: Wiley, pp. 311-385.

Seligman MEP (1995) The effectiveness of psychotherapy: The consumer reports study. American Psychologist 50(12): 965-974.

Totton N (1999) The baby and the bathwater: 'Professionalisation' in psychotherapy and counselling. British Journal of Guidance and Counselling 27(3): 313-324.

Wampold BE (2001) The Great Psychotherapy Debate: Models, Methods and Findings. Mahwah, NJ: Lawrence Erlbaum.

Wilensky HL (1964) The professionalization of everyone? The American Journal of Sociology 70(2): 137-158.

\section{Author biography}

Judi Miller is Associate Professor and Coordinator of Counsellor Education in the School of Health Sciences at the University of Canterbury (New Zealand). Her role includes educating counsellors, supervising counselling researchers and acting as critic and conscience for the development of the New Zealand Association of Counsellors. Her research interests include exploring the effectiveness of solution-focused training for counsellors; investigating the effects of a recent earthquake sequence on the practice of counsellors and examining the influence on counselling development 
of such diverse factors as third party funding, humour and recent pressure to privilege only evidence-based research. Recent publications include: Miller JH and Furbish DS (2013) Counseling in New Zealand. In: Hohenshil TH et al. (eds) Counseling around the World: An International Handbook. Alexandria: American Counseling Association, pp. 349-360; Miller JH (2012) Counselling and guidance initiatives in Aotearoa New Zealand. British Journal of Guidance and Counselling 40(3): 187-190; Miller J (2011) Marketing, advertising and ethics: Communicating with the public. In: Crocket K et al. (eds) Ethics in Practice: A Guide for Counsellors. Wellington: Dunmore Publishing, pp. 53-57. and Miller JH (2011) But wait, there's more: Evidence-based practice and researcher allegiance. Counselling Psychology Quarterly 24(2): 167-169. 